\title{
GRZECH SODOMSKI BOLESŁAWA SZCZODREGO W ŚWIETLE ROCZNIKÓW JANA DŁUGOSZA
}

\author{
Abstract \\ SODOM SIN OF BOLESLAUS II THE GENROUS \\ IN THE LIGHT OF JAN DEUGOSZ'S ANNALS
}

In the relation entered into the third volume of his Annals, dated 1076, Jan Długosz describing the Kiev campaign of Boleslaus the Generous introduces a description of the moral metamorphosis of the Polish ruler and accompanying knights. He maintains that they were guilty of a Sodom sin, which they committed in Ruthenia. This very phenomenon received the chronicler's decided anti-Ruthenian tone. The present article established the importance of Długosz's accusation and explains how this very element had its role in developing negative opinions about Ruthenians in the Annals. The author also provides background information about earlier accusations against Boleslaus regarding his sexual impurity.

Keywords: Jan Długosz, „Annals”, Boleslaus II the Generous, Sodom sin, Ruthenia Słowa kluczowe: Jan Długosz, Roczniki, Bolesław Szczodry, sodomia, Ruś

Przedmiotem niniejszego artykułu jest zagadnienie obecnego w Annales Jana Długosza motywu oskarżenia Bolesława Szczodrego o grzech sodomii. Ów zarzut został skierowany przez krakowskiego kanonika pod adresem polskiego władcy w narracji poświęconej jego kampanii kijowskiej, zanotowanej pod 1076 r. Zgodnie z kronikarskim przekazem na Rusi polski monarcha miał zakosztować grzechu contra naturam. Autorka zmierza do wskazania roli motywu zboczenia seksualnego Bolesława w Długoszowej narracji oraz wyjaśnienia, w jaki sposób ten wątek łączy się z konstruowanym przez dziejopisa negatywnym obrazem Rusinów w Rocznikach. Podstawę źródłową pracy stanowią przede wszystkim relacje Jana Długosza poświęcone panowaniu Bolesława Szczodrego oraz konfliktowi między tym 
władcą a biskupem Stanisławem zawarte w trzeciej księdze Annales. Analizie poddano również wcześniejsze źródła piśmienne, z których wynikały przesłanki o rozpustnym życiu Bolesława i uprawianiu przez niego sodomii. Pozwoliło to w konsekwencji na ukazanie kształtowania się i rozwoju tradycji oskarżeń monarchy o rozpustę i sodomię w polskim piśmiennictwie średniowiecznym.

Sodomia, należąca do katalogu grzechów cielesnych, umiejscowiona jest w obszarze seksualnej sfery człowieka. Termin nawiązuje do biblijnej Sodomy, zepsutego moralnie miasta, w którym, zgodnie z przekazem Księgi Rodzaju, nie znalazło się nawet dziesięciu sprawiedliwych ${ }^{1}$. Bezbożność mieszkańców sprawiła, że Sodoma została odrzucona przez Boga i spalona w „deszczu ognia i siarki”.

Chrześcijańscy moraliści doby średniowiecza potępiali wszelkie praktyki, które naruszały przyjęte normy współżycia seksualnego. Kościół kierował ostrze zakazów przeciw temu, co dla moralności chrześcijańskiej stanowiło największe zagrożenie, a mianowicie przeciwko rozwiązłości i rozpuście, grzechom zaliczanym do nieczystości (luxuria). Pojęcia nieczystości cielesnej używano w odniesieniu do aktów sprzecznych z zasadami uznawanej przez Kościół katolicki obyczajowości seksualnej. Należały do nich przede wszystkim: nierząd (fornicatio), konkubinat (concubinatus), cudzołóstwo (adulterium), zgwałcenie lub/i uprowadzenie kobiety w celu wzięcia jej za żonę (stuprum/raptus virginae), prostytucja (meretricia) oraz wszelkie stosunki określane mianem grzechu przeciw naturze (peccatum contra naturam, sodomia $)^{3}$ - najbardziej wieloznaczny z wyżej wymienionych terminów.

Pojęcie sodomii od początku nastręczało wiele trudności z jednoznaczną definicją tego zjawiska ${ }^{4}$. Określana również mianem „grzechu przeciw naturze”(peccatum contra naturam) była uznawana za śmiertelny grzech przeciw cnocie czystości ${ }^{5}$. Obydwa

1 Rdz 18, 32, [w:] Pismo Święte Starego i Nowego Testamentu, red. K. Dynarski, M. Przybył, wyd. 5 , Poznań 2008. Zob. także: J. Hojka, Sodoma i Gomora, „Ruch Biblijny i Liturgiczny”1961, vol. 14, nr 6, s. 285; A.R. Gołu chow sk i, Biblijna problematyka miasta Sodomy, „Kieleckie Studia Teologiczne” 2009 , t. 8, s. 309-334.

2 Rdz 19, 24-25.

3 Poszczególne akty omawia w swej pracy A. Kraw ie c: Seksualność w średniowiecznej Polsce, Poznań 2000, s. 46-243. Zob. także: K. Skwie rc zy ń ski, Mury Sodomy. Piotra Damianiego „Ksiega Gomory” i walka z sodomiq wśród kleru, Kraków 2011, s. 23-31.

4 Ewolucję w postrzeganiu zjawiska sodomii na przestrzeni wieków przedstawili m.in.: K. Rento Lings, Love Lost in Translation:Homosexuality and the Bible, Trafford Publishing, 2013, s. 241-440; R.M. Ka rra s, Seksualność w średniowiecznej Europie, tłum. A. B u gaj, Warszawa 2012, s. 184-190.

5 Na temat narodzin terminu „sodomia” zob.: K. Renato Lings, op. cit., s. 291, 294-298, 302-303; M.D. Jord an, The Invention of Sodomy in Christian Theology, Chicago 1997, s. 40-44; id e m, Sodomy, [w:] Gay Histories and Cultures. An Encyclopedia, (The Encyclopedia of Lesbian and Gay Histories and Cultures, vol. 2), ed. G. Ha gg e r t y, New York 2012, s. 829-831; K. Skw iercz yń sk i, Mury Sodomy..., s. 99100. Kształtowanie się pojęcia contra naturami jego użycie omówił H. P u ff: Nature on Trial. Acts „Against Nature" in the Law Courts of Early Modern Germany and Switzerland, [w:] The Moral Authority of Nature, eds. L. Daston, F. Vid a l, Chicago 2010, s. 232-253. 
przywołane wyżej terminy („sodomia” oraz „grzech przeciw naturze”) często były używane zamiennie na określenie szerokiego spektrum zachowań sklasyfikowanych przez ówczesnych teoretyków w trzech kategoriach, z których pierwszą stanowiło ratio generis-współżycie ze zwierzętami (z czasem zjawisko zaczęto określać terminem bestialitas), kolejną - ratio sexus - w jej ramach rozróżniano stosunki seksualne ze względu na płeć osób, ostatnią natomiast - ratio modi - stosunki płciowe odbywane w sposób uniemożliwiający poczęcie ${ }^{6}$. Uznanie sodomii jako grzechu wynikało z nauki Kościoła katolickiego. Rozumiano przez nią przede wszystkim wszelkie akty, które nie miały charakteru prokreacyjnego, a tym samym, zdaniem ówczesnych teologów, pozostawały w sprzeczności z nauką Kościoła, nierozerwalnie łączącą obydwie kwestie ${ }^{7}$. Takie pojmowanie grzechu „przeciwko naturze” widoczne jest między innymi w poglądach św. Tomasza z Akwinu, który rozwodząc się w Summa theologiae nad istotą rozpusty, stwierdził, że „występek przeciw naturze polega na czynnościach, z których to rozmnożenie nastąpić

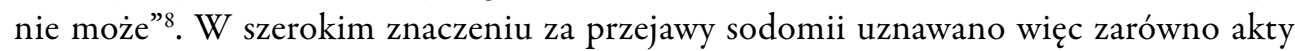
homoseksualne, jak i część heteroseksualnych. Sodomią określano także, jak wspomniano powyżej, zoofilię czy kontakty z „istotami nadprzyrodzonymi”, które zaliczane bywały niekiedy do kategorii bestialitas 9 .

W połowie XI w. zjawisko sodomii stało się przedmiotem pogłębionej refleksji Piotra Damianiego. Wyodrębnił on grzech sodomii spośród innych nieprokreacyjnych zachowań seksualnych, dokonał obszernej analizy zjawiska, wyróżnił cztery rodzaje stosunków sodomickich $^{10}$ i przedstawił ich zgubne konsekwencje ${ }^{11}$. Traktat włoskiego eremity Liber Gomorrhianusz 1049 r. piętnował grzech sodomii wśród przedstawicieli duchowieństwa

6 A. Krawiec, op. cit., s. 233; P. Le w an dow ski, Grzech sodomii w przestrzenipolitycznej, prawnej i spotecznej Polski nowożytnej, Wyd. E-bookowo, 2014, s. 55. Por. W. Joh hansson, W.A. Pe r c y, Homosexuality, [w: Handbook of Medieval Sexuality, eds. V.L. Bullough, J.A. B r und age, New York-London, 1996, s. 156. Z kolei popularny w Europie Zachodniej traktat Wilhelma Peraldusa, klasyfikując grzech „przeciw naturze", wyodrębnił jego dwa rodzaje. Szerzej na ten temat zob.: R.M. Ka rras, op. cit., s. 33. Zob. także podział grzechu sodomskiego w ujęciu Piotra Damianiego (K. Re n a to Ling s, op. cit., s. 298-299).

7 K. Skwierczyński, Walka z sodomiq wśród kleru -„Liber Gomorrhianus” Piotra Damianiego, „Przegląd Humanistyczny" 2007, t. 98, z. 3, s. 372; id e m, op. cit., s. 36; H. Za re m ska, Grzech i występek. Normy i praktyka moralności spotecznej, [w:] Kultura Polski średniowiecznej XIV-XVw., red. B. Ge re mek, Warszawa 1997, s. 571; R.M. Karras, op. cit., s. 165, 184. Na temat postaw społeczeństw wobec zachowań „przeciwko naturze” w średniowiecznej Europie Zachodniej zob. P. Le w a n d ow sk i, op. cit., s. 24-51.

8 Tomasz z Akwinu, Suma teologiczna, t. 22: Umiarkowanie, thum. S. Bełch, London 1993, art. 11, s. 93. Poglądy św. Tomasza z Akwinu na grzech contra naturam przedstawił K. Ren ato Lings, op. cit., s. 301-302; M.D. Jo rd a n, The Invention of Sodomy..., s. 136 i n.

9 A. Krawiec, op. cit., s. 241-243.

10 W ujęciu Piotra Damianiego odmianami tego grzechu były: masturbacja, wzajemna masturbacja, stosunki międzyudowe oraz stosunki analne. Zob. K. Renat o Lings, op. cit., s. 298-299; K. Skwierczyński, Mury sodomy..., s. 106; P. Lew a nd ow ski, op. cit., s. 41.

11 K. Skwierczyński, Mury sodomy..., s. 108 i n. 
Kościoła katolickiego, rozumiany jako męskie stosunki homoseksualne ${ }^{12}$. Ujęcie sodomii w takich kategoriach wpłynęło na zawężenie omawianego pojęcia, które począwszy od XIII w., zaczęto utożsamiać z zachowaniami homoseksualnymi mężczyzn, choć nie zatraciło ono swego wielowymiarowego znaczenia ${ }^{13}$. W średniowiecznych źródłach zachowania homoseksualne określane są najczęściej mianem „sprzecznych z naturą” (contra naturam) bądź jako grzech sodomii (fornicatio sodomita, sodomitico more, sodomitico ritu, in celere sodomitico, sodomiticum peccatum $)^{14}$.

Zarzut sodomii został skierowany przez Jana Długosza pod adresem Rusinów w narracji opowiadającej o panowaniu Bolesława Szczodrego oraz konflikcie między monarchą a biskupem Stanisławem. W relacji zanotowanej pod 1076 r., dotyczącej pobytu Bolesława i jego oddziałów w obozie zimowym w Kijowie, Długosz opisał moralne zepsucie obyczajów Bolesława i towarzyszących mu oddziałów, przypisując polskiemu władcy grzech sodomii, w którym, zgodnie z kronikarskim przekazem, miał zakosztować na Rusi: „Nec simplici libidinum genere contentus in spurcissimum Sodomie scelus, Ruthenorum detestabiles mores, apud quos scelus illud in usu erat, imitatus, fedissime prolapsus est" ${ }^{15}$.

Długoszowe przekazy nie mogą być traktowane jako podstawowe źródło poznania historii panowania Bolesława Śmiałego ani też dziejów zatargu biskupa krakowskiego Stanisława z królem. Dziejopis wykorzystał wiadomości na powyższy temat z wcześniejszych źródeł piśmiennych, z których między innymi wynikały przesłanki o rozpustnym życiu

12 Traktat Piotra Damianiego Liber Gomorrhianus stał się przedmiotem wnikliwych badań Krzysztofa Skwierczyńskiego (i d e m, Mury Sodomy...; i d e m, Walka z sodomiq..., s. 369-382) oraz Edoarda D’A n l g e lo (San Pier Damiani, „Liber Gomorrhianus”. Omosessualita ecclesiastica e rifonna della Chiesa, Alessandria 2001). Zagadnienie walki z sodomią przez Piotra Damianiego poruszają w swych pracach również m.in. K. Ren at o Lings, op.cit., s. 297-300; M.D. Jord a n, The Invention of Sodomy..., s. 45 i n.; R.M. Ka r r as, op. cit., s. 185.

13 B.-U. Herge mölle r, Średniowiecze, [w:] Geje i lesbijki. Życie i kultura, red. R. Ald rich, thum. P. No wakowski, Kraków 2009, s. 57; K. Skwierczyński, Mury Sodomy...,s. 36; R.M. Karras, op. cit., s. 185. Pojęcie grzechu sodomskiego w odniesieniu do homoseksualizmu upowszechniło się od czasów św. Tomasza z Akwinu (A. Krawi e c, op. cit., s. 237; K. Renato Lings, op. cit., s. 302-303), który wyjaśnił w swej Sumie teologicznej, że „grzech zwany «sodomskim» popełnia ten, kto spółkuje z osobnikiem tej samej płci: mężczyzna z mężczyzną, kobieta z kobietą" (Tomasz z Akwinu, op. cit., s. 93). W tym czasie na określenie stosunków ze zwierzętami wprowadzono termin bestialitas. Zob. A. Kr a w i e c, op. cit., s. 237; B.-U. Herge mölle r, Sodomiter. Schuldzuschreibung und Repressionformen im späten Mittelalter, [w:] Randgruppen der spätmittelalterlichen Gesellschaft. Ein Hand-und Studienbuch, Hrsg. B.-U. Herg emöller, Warendorf 1994, s. 319.

14 K. Skwierczy ński, Mury sodomy..., s. 36. Należy zwrócić uwagę, że zarówno polskie, jak i ruskie źródła niemal zupełnie milczą na temat wykroczeń contra naturam, w przeciwieństwie do źródeł pochodzących z Europy Zachodniej, w których zachowały się liczne wiadomości na ten temat. Jak zauważył A. Krawiec, jedynym przypadkiem sodomii, szerzej komentowanym przez polskich pisarzy doby średniowiecza, jest postać Bolesława II Szczodrego. Zob. A. Kr a w i e c, op. cit., s. 233.

15 Ioannis Dlugossii Annales seu Cronicae incliti Regni Poloniae, lib. III-IV, Varsaviae 1970, s. 121 [dalej: Ioannis Dlugossii Annales]. 
Bolesława i uprawianiu przez niego sodomii ${ }^{16}$. Niemniej obok wcześniejszych wątków, które weszły do kanonu opowieści o panowaniu Bolesława Szczodrego i podania o św. Stanisławie, Jan Długosz wprowadził do narracji liczne amplifikacje i uzupełnienia zarówno w sensie słownym, jak i faktograficznym.

Punktem wyjścia do nakreślenia wizerunku Bolesława II przez Długosza jest literacka wizja czasów jego panowania pióra Wincentego Kadłubka, która otwiera cykl doniesień o konflikcie biskupa z królem ${ }^{17}$. W opinii Tadeusza Grudzińskiego Mistrz Wincenty, w którym niektórzy upatrują pierwszego hagiografa św. Stanisława, położył literackie podwaliny pod przyszły kult biskupa ${ }^{18}$. Historia konfliktu między obydwoma bohaterami podania w ujęciu Wincentego Kadłubka różni się od lakonicznego przekazu Anonima zw. Gallem, choć w jego podaniu zachowany został Gallowy porządek wydarzeń i ich umiejscowienie w czasie. Na kształt Kadłubkowej narracji, która powstała przeszło wiek po opisywanych przez niego wydarzeniach, mogły, zdaniem Tadeusza Grudzińskiego, wpłynąć znajomość przez kronikarza zapisków rocznikarskich, w tym w pierwotnej zaginionej redakcji Rocznika kapituty krakowskiej, oraz tradycja ustna utrwalona w krakowskim środowisku kapitulnym ${ }^{19}$. Narracja o władcy, w której Mistrz Wincenty główny nacisk położył na przedstawienie dramatu króla i biskupa, składa się z dwóch nierównych części ${ }^{20}$. Portret Bolesława, wyraźnie dwubarwny, początkowo przedstawia go jako wzorowego monarchę, obdarzonego wszystkimi cechami dobrego władcy. Z czasem wizerunek staje się przesycony czarnymi barwami, ukazując króla jako tyrana, będącego zaprzeczeniem wszelkiej rycerskości ${ }^{21}$. Niemniej zarówno w przekazie Galla, jak i Mistrza Wincentego nie odnajdujemy oskarżeń o rozpustę i skłonności do grzechu sodomskiego, kierowanych pod adresem monarchy.

16 Kształtowanie się legendy Bolesława Szczodrego w średniowiecznym kronikarstwie polskim najpełniej przedstawił J. B an aszkiewicz, Czarna i biata legenda Bolestawa Śmiatego, „Kwartalnik Historyczny” R. 88, 1981, nr 2, s. 353-383. Zob. także K. B enyskiewicz, W kregu Bolestawa Szczodrego i Wtadystawa Hermana. Piastowie w matżeństwie, polityce i intrydze, Wrocław 2010, s. 88-100; J. Pow ierski, Kryzys rząów Bolestawa Śmiatego. Polityka i jej odzwierciedlenie w literaturze średniowiecznej, Gdańsk 1992, s. 131-175; M. Plezi a, Dookota sprawy św. Stanistawa. Studium źródłoznawcze, Bydgoszcz 1999, s. $65-150$.

17 J. Banaszkiewicz, Czarna i biata legenda..., s. 354 .

18 T. Grudziński, Bolestaw Śmiaty-Szczodry i biskup Stanistaw. Dzieje konfliktu, Warszawa 1986, s. 206.

19 Ibidem, s.138.

20 Ibidem, s. 140. Zob. także N. Delestowicz, Bolestaw II Szczodry. Tragiczne losy wielkiego wojownika 1040/1042-2/3 IV 1081 albo 1082, Kraków 2016, s. 266-292; S. Ku z m o vá, Preaching Saint Stanislaus. Medieval Sermons on Saint Stanislaus of Cracov and Their Role in the Construction of His Image and Cult,Budapest 2010, s. 14-17.

21 J. B a naszki ew icz, Czarna i biata legenda..., s. 355; B. Kü r b is, Jak mistrz Wincenty pojmowat historie Polski, „Studia Źródłoznawcze”1976, t. 20, s. 68; J.Powierski, op. cit., s. 131, 137-138; E. Skibiński, Biskup i monarcha, [w:] Docendodiscimus. Studia historyczne ofiarowane Profesorowi Zbigniewowi Wielgoszowi w siedemdziesiąta rocznicę urodzin,red. K. Ka c z ma rek, J. Ni ko d e m, Poznań 2000, s. 103. 
Wiadomości o nieczystych skłonnościach Bolesława Szczodrego jako pierwszy przekazał Wincenty z Kielc. Dominikański hagiograf odsłonił moralną nieczystość władcy w Żywocie mniejszym św. Stanistawa (Vita minor), a następnie w bardziej rozbudowanej wersji tego utworu, jaką jest Żywot większy św. Stanistawa (Vita maior) ${ }^{22}$. Opierając się na Wincentyńskiej narracji, XIII-wieczny hagiograf wyostrzył opisywane w Vita minor wydarzenia. Rysując tło konfliktu między Bolesławem a biskupem Stanisławem, poprzedził opis okoliczności prowadzących do jego wybuchu słowami, które rzucają cień na sylwetkę moralną władcy: „Bolezlaus etenim intermisso studio uirtutum sentina factus est omnium uiciorum et carnis sue sequens luxuriam, gloriam suam in ignominiam et naturalem usum mutavit in eum usum, qui est contra naturam"23. W drugiej, obszerniejszej biografii św. Stanisława pióra Wincentego z Kielc wątek nieczystości monarszej został wzbogacony o dodatkowe elementy. W Vita maior hagiograf połączył upadek moralny władcy z wieloletnim pobytem Bolesława wśród niechrześcijańskich ludów ${ }^{24}$. Prezentując sylwetkę moralną monarchy, Wincenty uzupełnił wcześniejszy zapis zanotowany w Vita maior mówiący o nieczystości Bolesława II ${ }^{25}$.

Elementy wprowadzone przez Wincentego z Kielc do Żywotów św. Stanistawa posiadają ogromne znaczenie dla kształtującej się później tradycji o Bolesławie Szczodrym. W zawiłym i niejednoznacznym przekazie zawartym w Vita maior, w którym brak jednoznacznego pomówienia monarchy o seksualne występki, czyhała, jak określił to Jacek Banaszkiewicz, „bomba zegarowa”, mająca wkrótce wybuchnąć otwartymi oskarżeniami króla o rozpustne życie seksualne i współżycie ze swoją klaczą ${ }^{26}$. Przytoczony wcześniej passus zawarty w Vita maior stał się źródłem rozpowszechnionego już od schyłku XIII w. poglądu o uprawianiu przez Bolesława sodomii ${ }^{27}$.

Niewielki wpływ na dalszy rozwój średniowiecznej tradycji piśmiennej o Bolesławie Szczodrym posiada przekaz zawarty w Kronice Dzierzwy ${ }^{28}$. Pomówienie władcy

22 Na temat wizerunku św. Stanisława w dziełach Wincentego z Kielc zob. M. Ple zi a, Dookoła sprawy..., s. 140-150; J. B a naszki e wi icz, Czarna i biata legenda..., s. 356-364; S. Ku z mová, op. cit., s. 23-34.

23 Vita sancti Stanislai episcopi Cracoviensis (Vita minor), [w:] Monumenta Poloniae Historica, t. 4, ed. W. Kętrzyński, Lwów 1884, s. 278.

24 J. Banaszkieiwcz, Czarna i biata legenda..., s. 359.

25 Fragment monarszej charakterystyki został wzbogacony o passus mówiący, że Bolesław był „[...] traditus quoque in reprobum sensum, sicut equus et mulus, quibus non est intellectus passionibus ignomine et contumelie affectus, Vita sancti Stanislai episcopi Cracoviensis", Vita sancti Stanislaiepiscopi Cracoviensis (Vita maior), [w:] Monumenta Poloniae Historica, t. 4, s. 384. Zob. także: J. B a n s z ki e w i z, Czarna i biata legenda..., s. 362. Powyższy urywek został w narracji płynnie połączony z wcześniejszym zapisem znanym z Vita minor („carnis sue sequens luxuriam, gloriam suam in ignominiam et naturalem usum mutavit in eum usum, qui est contra naturam), Vita sancti Stanislai episcopi Cracoviensis (Vita maior)..., s. 384. Por. Vita sancti Stanislaepiscopi Cracoviensis (Vita minor)..., s. 278. Zob. także: M. Ple zi a, Dookota sprawy..., s. 149.

26 M. Plezia, Dookota sprawy..., s. 159; J. B a naszkiew icz, Czarna i biata legenda..., s. 363.

27 J. Banaszkiewicz, Czarna i biata legenda..., s. 359.

28 Chronica Dzirsvae, [w:] Monumenta Poloniae Historica, Nova Series, t. 15, wyd., wstępem i przyp. opatrzył K. Pawłow ski, Kraków 2013, s. 26-30. Zob. także: M. Ple zi ia, Dookota sprawy..., s. 150. 
o sodomickie skłonności odnajdujemy w Kronice polsko-ślaskiej ${ }^{29}$ oraz w Kronice wielkopolskiej. W ostatnim z wymienionych powyżej źródeł kronikarz, powołując się na znane mu doniesienia mówiące o uprawianiu przez króla sodomii, zaznaczył, że nie daje im wiary. Postępowanie władcy wytłumaczył jego wstrętem do kobiet, które podczas nieobecności mężów dopuściły się niewierności ${ }^{30}$.

Przekazy Jana Długosza zawarte w Rocznikach oraz w Vita sanctissimi Stanislai Cracoviensis episcopi ${ }^{31}$ stanowią kolejny etap w rozwoju tradycji o Bolesławie Śmiałym i św. Stanisławie $^{32}$. Dziejopis rozwinął w Rocznikach nieprzychylny królowi fragment monarszej biografii mówiący o jego rozpuście i sodomickich skłonnościach. Wątek zepsucia moralnego Bolesława, do którego doszło w czasie pobytu polskich oddziałów w obozie zimowym w Kijowie po zwycięskiej wyprawie ruskiej, ukoronowanej powtórnym zdobyciem stolicy Rusi, został umieszczony w narracji pomiędzy opowiadaniem o militarnych sukcesach polskiego władcy a obszernym wątkiem dotyczącym konfliktu władcy z biskupem krakowskim Stanisławem. Dzięki licznym uzupełnieniom i amplifikacjom wprowadzonym do narracji tło tego zatargu zostało przez kronikarza nakreślone szerzej niż w źródłach naczelnych. Jego początek przypada w Rocznikach na 1074 r. Pod tym rokiem dziejopis wprowadził do narracji wątek miłosny Bolesława II z Krystyną, piękną żoną rycerza Mściwoja z Bużeni$\mathrm{na}^{33}$. Porwanie tej zacnej matrony i uczynienie z niej nałożnicy Bolesława II doprowadziło do pierwszego zatargu władcy z biskupem Stanisławem. Umieszczenie tego motywu pełni

29 Autor Kroniki polsko-śląskiej, wymieniając katalog nieprawości Bolesława, zanotował, że Bolesław współżył wbrew naturze z klaczą: „[Boleslaus] flagiciosus cum equa contra naturam effectus, Chronica polonorum, [w:] Monumenta Poloniae historica, t. 3, ed. L. Ćwikliński, Lwów 1878, s. 624. Zob. także: W. Mro zo wi c z, Święty Stanisław w średniowiecznym dziejopisarstwie śląskim, [w:] Kult św. Stanistawa na Śląsku (1253-2003), red. A. Pobóg - L e na r to w icz, Opole 2004, s. 118-124. Na temat koncepcji sodomickiego aktu płciowego z klaczą obecnej w kulturze indoeuropejskiej i mitologii greckiej zob. K. B enyskiewicz, op. cit., s. 95-100. Historyk ten wysunął hipotezę o mitologicznej inspiracji twórców legendy Bolesława Szczodrego dziejami króla Lapidów Iksjona. Ibidem, s. 99-100.

30 „In tantumque cultum detestabatur femineum, quod loco uxoris iumentum purpura et bysso decoratum ad omne iter quo ibat, secum duci faciebat. Quedam autem scripture quibus standum est verius asserunt, quod non, sed in detestacionem sceleris per mulieres nobiles in suorum maritorum absencia perpetrati hoc se facere demonstrabat", Chronica Poloniae Maioris, ed. B. Kür r bis, [w:] Monumenta Poloniae Historica, Nova Series, t. 8, Warszawa 1970, cap. 14, s. 22.

31 Vita sanctissimi Stanislai, ed. I. Polkow sk i, Ż. Pa u li, [w:] Joannis Dlugossii Senioris Canonici Cracoviensis, Opera omnia, t. 1, Kraków 1887, s. 1-181. Jan Długosz zamieścił także zwięzłą biografię św. Stanisława w Katalogu biskupów krakowskich, która powstała u schyłku życia dziejopisa. Joannis Dl u g o ss i i, Vita episcoporum Poloniae, Opera omnia, t. 1, Kraków 1887, s. 387-389.

32 Wizerunek św. Stanisława w dziełach Jana Długosza omówiła S. Ku z m o vá, op. cit., s. 43-51. Na temat różnic w Długoszowych relacjach dotyczących św. Stanisława zawartych w Vita sanctissimiStanislaii w Rocznikach zob. M. Ple zi a, Dookota sprawy..., s. 153-161. Zob. także: K. Kro to ski, Święty Stanistaw biskup w świetle źródet. Rozbiór krytyczny źródet odnoszacych się do kwestyi Ś. Stanistawa bisk., Kraków 1902, s. 76-104.

33 Ioannis Dlugossii Annales, lib. III, s. 115-116. 
w strukturze narracji określoną rolę - pozwoliło na zasygnalizowanie niepohamowanej chuci monarchy.

Kolejna odsłona wyprawy kijowskiej, której opis został zanotowany pod 1075 i 1076 r., była dla dziejopisa okazją do przedstawienia sukcesów politycznych Bolesława i ukazania jego zalet jako dobrego władcy. W Annales, podobnie jak w źródłach przeddługoszowych, militarne sukcesy Bolesława II zostały ukazane jako źródło przyszłych niebezpieczeństw ${ }^{34}$. Po zwycięskiej kampanii kijowskiej, zgodnie z przekazem Długosza, zanotowanym pod 1076 r., nastąpiło przeobrażenie moralne Bolesława Szczodrego i jego rycerzy. W ujęciu kronikarza polskiego władcę i jego wojowników do upadku moralnego doprowadziło rozpustne życie i pijaństwo, których ci dopuszczali się w stolicy Rusi. Wydarzenia, do których doszło w czasie pobytu polskiego rycerstwa w Kijowie, spowodowały demoralizację i spadek wartości bojowej oddziałów Bolesława, o czym świadczą słowa kronikarza:

Ex mora, qua in civitate Kyowiensi hibernatum est, universi exercitus Polonici robur et disciplina elanguit in eamque perniciem ex voluptatibus, comesacionibus, ebrietatibus et libidinibus tam Boleslaus Polonie rex quam milites sui, paucis exceptis, deiecti sunt, ut plus nocuerit vicisse, quam victoria caruisse victoriaque potiri multo magis discriminis quam comodi ingessit ${ }^{35}$.

Zapewnienie porządku i utrzymanie właściwej karności w oddziałach należało do powinności Bolesława jako dowódcy, z których ten, zdaniem kronikarza, się nie wywiązał. Istotną rolę w utrzymaniu dyscypliny odgrywało przestrzeganie norm religijnych, obyczajowych oraz etosu rycerskiego ${ }^{36}$. Powyższe zarzuty tracą jednak swą wagę w obliczu grzechu, jakiego dopuścił się sam Bolesław Śmiały, który „popadł w haniebny i plugawy grzech sodomski, naśladując godne potępienia zwyczaje Rusinów, u których to zboczenie było pospolite" ${ }^{37}$. Przemiana moralna Bolesława stanowi w Rocznikach preludium do wybuchu otwartego konfliktu z krakowskim biskupem i upadku monarchy.

${ }_{34}$ W przekazie Jana Długosza po zwycięskiej kampanii wojennej zakończonej zdobyciem całej Rusi ("Eo memorabili confecto Kyowyaque in dicionem subacta, cum universa Russia pacata esset", Ioannis Dlugossii Annales, lib. III, s. 120), Bolesław Szczodry popadł w niepohamowaną pychę. Odniesione zwycięstwo natomiast przyniosło, zdaniem kronikarza, więcej szkód niż korzyści (ibidem, s. 120-121). Por. Magistri Vincentidicti Kadtubek Chronica Polonorum, ed. M. Plezia, [w:] Monumenta Poloniae Historica, Nova Series, t. 11, Kraków 1994, lib. II, cap. 18, s. 54-55.

35 Ioannis Dlugossii Annales, lib. III, s. 120.

36 A. Nadolski, J. Dan kowa, Uwagi o sktadzie i uzbrojeniu polskiej jazdy rycerskiej w latach 1350-1450, „Studia i Materiały do Historii Wojskowości” 1983, vol. 26, s. 93-94.

37 Jana Dtugosza Roczniki czyli Kroniki Stawnego Królestwa Polskiego, ks. III-IV, tłum. J. M r u ków n a, Warszawa 2009, s. 142 [dalej: Jana Dtugosza Roczniki]. W Annales dziejopis nie precyzuje, na czym dokładnie polegało haniebne, sprzeczne z naturą postępowanie Bolesława. Kronikarz uściślił przekaz w Żywocie św. Stanistawa, notując, iż władca odbywał akty płciowe z krową (cum iumentis). Vita sanctissimi Stanislai..., s. 46. 
W dalszej kolejności kronikarz, podążając za przekazami źródeł prymarnych, opowiada o zdradach żon polskich rycerzy, których te dopuściły się w czasie długiej nieobecności swych mężów w kraju. Opowieść o Bolesławie Szczodrym dochodzi do punktu kulminacyjnego w chwili, gdy wraca on z Rusi do Polski i wymierza surową karę swoim rycerzom, którzy na wieść o niemoralnym prowadzeniu się swych żon bez wiedzy i zgody króla wrócili do kraju. Kronikarz wytłumaczył wydarzenia, do których doszło w ojczyźnie podczas ich nieobecności, jako słuszną karę zesłaną na polskie rycerstwo przez Boga za rozpustne postępowanie w czasie pobytu w Kijowie ${ }^{38}$. Bolesław nie poprzestał na ukaraniu swych rycerzy. Surową karę wymierzył również ich niewiernym żonom, nakazując przystawić szczenięta do ich piersi zamiast niemowląt ${ }^{39}$.

W kronice Mistrza Wincentego przeobrażenie moralne Bolesława Szczodrego, przekreślające jego dotychczasowe zasługi wobec ojczyzny, dokonało się w trakcie akcji represyjnej skierowanej przeciwko rycerzom-uciekinierom, którzy, na wieść o niemoralnym prowadzeniu się ich żon, bez zezwolenia króla opuścili obóz w Kijowie ${ }^{40}$. Kadłubek, konfrontując następnie dwie, niepasujące do siebie natury moralne Bolesława, wyjaśnił, że miód zamienił się w piołun, a oliwka w oleaster ${ }^{41}$. Jan Długosz inaczej objaśnił upadek moralny monarchy. W ujęciu XV-wiecznego historyka przyczyną przemiany moralnej Bolesława był kontakt z mieszkańcami Kijowa, grzesznej metropolii Rusi, i zasmakowanie w miłosnych rozkoszach, jakie oferowała ruska stolica i jej mieszkańcy. Kronikarz, podkreślając zalety Kijowa jako miasta obfitującego we wszelką żywność („Omnium siquidem victualium, que cuilibet gule sufficiunt, Kyowia ferax est, carne, melle, pisce et frumento fertilissima” ${ }^{42}$ ), nie tylko akcentuje zamożność ruskiej stolicy, ale również sygnalizuje niebezpieczeństwo wynikające z obfitości pożywienia, które stwarzało sytuacje sprzyjające oddawaniu się rozrywkom, pijaństwu i rozwiązłości obyczajowej ${ }^{43}$. Kreując w narracji wizerunek mieszkanek Kijowa, dziejopis

38 „Deo hanc Polonis iuste immittente pro libidinibus in Kyow admissis ulcionem, excepit”, Ioannis Dlugossii Annales, lib. III, s. 123.

39 Ioannis Dlugossii Annales, lib. III, s.123. Por. Magistri Vincentii dicti Kadtubek Chronica Polonorum, lib. II, cap. 18, s. 56. Na temat motywu przystawiania szczeniąt do piersi karmiących matek w kronikarstwie średniowiecznym zob. P. Ż mu d zki, Wtadca i wojownicy. Narracje o wodzach, drużynie i wojnach wnajdawniejszej historiografii polskiej i ruskiej,Wrocław 2009, s. 77-81. Zob. także: M. Ple zi a, Od Arystotelesa do „ztotej legendy”, Warszawa 1959, s. 306-313.

40 J. Banaszkiewicz, Czarna i biata legenda..., s. 354.

41 „Extunc in oleastrum oliua et fauus uersus est in absintium”. Magistri Vincentii dicti Kadtubek Chronica Polonorum, lib. II, cap. 18, s. 56.

42 Ioannis Dlugossii Annales, lib. III, s. 120.

43 B. Geremek, Cztowiek i zabawa: kultura ludyczna, [w:] Kultura Polski średniowiecznej..., s. 518. W średniowieczu potępienie rozpusty (luxuria) często szło w parze z potępieniem obżarstwa (gula). Zob. J. Le Goff, N. Tru on g, Historia ciata w średniowieczu, thum. I. Ka n i a, Warszawa 2006, s. 43, s. 48-49; por. M.W. Blo o m field, The Seven Deadly Sins: An Introduction to the History of a Religious Concept, with Special Reference to Medieval English Literature, Michigan 1952, s. 127; E. Wółki ewicz, Grube ciato. Spoteczne postrzeganie otytości w średniowieczu, „Przegląd Historyczny” 2009, t. 100, z. 3, s. 511-517. Na 
posłużył się często spotykanym w średniowiecznym piśmiennictwie zabiegiem literackim o wymowie moralnej, polegającym na zestawieniu niezwykłej urody kobiet z ich zepsuciem moralnym: „feminas habens statura proceres, crine glaucas et speciosas, sed lascivas”“44.

Oryginalne uzupełnienie narracji przez Długosza o niemający potwierdzenia źródłowego motyw rozpustnych kobiet, ukazanych jako uwodzicielki o niemoralnej obyczajowości, posłużyło zaprezentowaniu ich w charakterze sprawczyń negatywnych postaw moralnych i obyczajowych polskiego rycerstwa i Bolesława Szczodrego. W przeciwieństwie do większości średniowiecznych źródeł, w których mężczyźni byli przedstawiani jako strona inicjująca kontakty cielesne ${ }^{45}$, Jan Długosz wprowadził wątek kobiet, również obecny w średniowiecznym pisarstwie, jako inicjatorek ewolucji moralnej panującego ${ }^{46}$.

Rozpustne postępowanie króla i jego rycerzy stało w sprzeczności z moralnością średniowieczną, w której istotne miejsce zajmowało panowanie nad ciałem i płciowością ${ }^{47}$. Ówczesny model religijności nie dopuszczał form pożycia seksualnego naruszających przyjętą przez chrześcijaństwo koncepcję życia płciowego, w tym rozpusty i sodomii. Średniowieczni kronikarze chwalą u władców „powściągliwość od chuci”, ganią natomiast rozpustę oraz wszelkie niezgodne z nakazami chrześcijaństwa poczynania ${ }^{48}$. Rozpusta, będąca zniewagą czynioną

temat symboliki uczt organizowanych przez panujących na królewskich dworach zob. np. M. B a r t n icki, Wtadca i poddani w historiografii ruskiej XI-XIII wieku, Lublin 2015, s. 181-184; J. B a naszkie wicz, Trzy razy uczta, [w:] Spoteczeństwo Polski średniowiecznej, t. 5, red. S. K. Kuczyńsk i, Warszawa 1992, s. 95-108; M. Dy g o, Uczty Bolestawa Chrobrego, „Kwartalnik Historyczny” R. 112, 2005, nr 3, s. 41-54.

44 Ioannis Dlugossii Annales, lib. III, s. 120.

45 R.M. Karras, op. cit., s. 167-168.

46 Na temat wplywu kobiet na przemiany moralne panujących zob. np. G. Pac, Kobiety w dynastii Piastów. Rola spoteczna piastowskich żon i córek do potowy XII wieku-studium porównawcze, Toruń 2013, s. 39 i n.

47 J. Le Goff, N. Truong, op. cit., s. 44.

48 Motyw rozwiązłości władców obecny jest w tradycji historiograficznej wielu krajów, w tym Rusi. W Povest'i vremennych let Nestor, opowiadając o wizycie misjonarzy trzech religii u Włodzimierza Wielkiego, gani rozpustne obyczaje Bułgarów (Poviest' vremennych let, č. 1, wyd. D.C. L i ch a č ev, Moskwa-Leningrad 1950, s. 258-259). Nieprzychylnie wypowiada się również o samym Włodzimierzu Wielkim. Opisując pogański okres życia tego władcy, ruski latopisarz zanotował, że był on ,wielce chutliwym”, niesytym rozpusty lubieżnikiem (ibidem, s. 254-255; wizerunek Włodzimierza Wielkiego w historiografii ruskiej od końca XI do połowy XIII stulecia przedstawił M. Bartn icki: op. cit., s. 153-184). Ten sam kronikarz w relacji poświęconej śmierci Wsiewołoda Jarosławowicza, wymieniając jego zalety, zanotował, że był on „powściągliwy od pijaństwa i chuci”(Povest' vremennych let..., s. 343). Zob. także Pouczenie Wtodzimierza Monomacha, zanotowane pod 1096 r. w Povest'i vremennych let.W tym cennym zabytku literatury staroruskiej, który zgodnie ze słowami autora adresowany był do jego synów, odnajdujemy bogactwo treści odnoszących się do sfery obyczajowej. Włodzimierz, zalecając $w$ Pouczeniu pobożne postępowanie, nakazuje „oczy mieć na wodzy, język powściągać, rozum upokarzać, ciało ujarzmiać, gniew wytępiać, myśli mieć czyste, pobudzając do dobrych uczynków dla Pana" (ibidem, s. 356). W innym miejscu władca przestrzega przed kłamstwem, pijaństwem i wszeteczeństwem, tłumacząc, że „przez to gnije dusza i ciało” (ibidem, s. 354). W średniowiecznym kronikarstwie ruskim niejednokrotnie pojawia się motyw wzajemnego obarczania się zarzutem rozpusty przez wyznawców Kościołów katolickiego i prawosławnego. Zob.: F. S i el i cki, Polsko-ruskie stosunki kulturalne do końca XV wieku, Wrocław 1997, s. 37-38. 
Bogu, znalazła się z czasem w kanonie grzechów głównych wśród nagannych wykroczeń seksualnych ${ }^{49}$. Średniowieczna etyka seksualna wymagała, aby człowiek żonaty dotrzymywał wierności, a samotny żył w czystości ${ }^{50}$. Nieprzyzwoite zachowanie cudzołożących stanowiło zagrożenie dla istniejącego porządku społecznego ${ }^{51}$. Jan Długosz, ostro piętnując naruszenie przez polskiego władcę i jego rycerzy norm religijnych i obyczajowych, udziela jednocześnie lekcji moralności. W Długoszowych przekazach grzech sodomii, obok okrucieństwa, a później zabójstwa biskupa Stanisława, stał się głównym rysem królewskiej hańby, przypominanym wielokrotnie przez kronikarza na kartach Annales $^{52}$. W Długoszowej narracji, obrazującej konflikt króla z biskupem, zarzut sodomii stał się jednym z głównych elementów napomnień, jakich św. Stanisław miał udzielić Bolesławowi ${ }^{53}$.Z lektury passusów, w których Jan Długosz powraca do wątku królewskiej sodomii, wyczytać można osobiste przekonanie dziejopisa na temat grzechu contra naturam, którym Bolesław II splamił godność królewską ${ }^{54}$. Jan Długosz na kartach Annales poruszył kwestię obyczajowości seksualnej nie tylko Bolesława Szczodrego, lecz także innych władców. Przykładem może być postać Władysława Warneńczyka. W opisie śmierci tego władcy w bitwie pod Warną kronikarz zanotował wiadomość, że Warneńczyk był in marium libidinem proclivus ${ }^{55}$. Powyższa wzmianka stała się później podstawą do formułowania opinii na temat homoseksualnych skłonności króla ${ }^{56}$.

49 J. Le Goff, N. Truong, op. cit., s. 42.

50 H.Zaremska, op. cit., s. 566.

51 R.M. Ka r ra s, op. cit., s. 170. Na znaczenie rozwiązłości jako zachowania podważającego normy społeczne zwrócił uwagę P. Ż m u dzki, Mieszko I i Amazonki. Wspólnoty wojownicze i normy życia rodzinnego w relacji Ibrahima ibn Jakuba,[w:] Tekst źródta, krytyka, interpretacja, red. B. Trelińska, Warszawa 2005, s. 99-107. Szerzej na temat cudzołóstwa zob.: A. Kr a wi e c, op. cit., s. 130-160.

52 Zob. Ioannis Dlugossii Annales, lib. III, s. 123, 126-127, 129-130, 133, 144-145. W relacji zanotowanej pod $1076 \mathrm{r}$. kronikarz wprost napisał, że w grzech przeciwny naturze Bolesław popadł w czasie pobytu na Rusi: „Hec cum per se detestanda essent, omnibus tamen hiis detestabilius, quod rex Boleslaus usurpatum in Russia lastivum et brutalem contra naturam usum auxisse, non remisisse videbatur", Ioannis Dlugossii Annales, lib. III, s. 123.

53 Zob. IoannisDlugossii Annales, lib. III, s.127, s. 130, s. 133.

54 Przekonanie, że Bolesław Szczodry haniebnym grzechem sodomskim splamił zarówno godność królewską, jak i godność własnego rodu, zawarł kronikarz w relacji zanotowanej pod 1077 r. w formie napomnienia udzielonego przez biskupa Stanisława grzesznemu władcy: „[...] ne dignitatem regalem et genus nobilissimum feda peccati contra naturam contagione inquinet, ne ut iumentum in suo stercore putrescens se Deo et hominibus odibilem et invisum faciat, ne gloriam suam et victoriarum variarum ab Optimo Deo largitarum titulos ignominia sempiterna sibi et sue domui iniurenda prostituat et commutet, sed, si permissa voluptate carnali uti libet, cum uxore pocius procreandorum filiorum causa illam expleat [...]", Ioannis Dlugossii Annales, lib. III, s. 127. Zob. także A. Kr aw i c, op. cit., s. 236-237.

55 Joannis Dlugossii Annales seu cronicae incliti regni Poloniae, lib. XI-XII, Varsaviae 2001, s. 327.

56 Na temat orientacji homoseksualnej Władysława Warneńczyka zob. S.A. Sroka, Stawa, chwata i plotka. Wtadystaw Warneńczyk jako król Wegier, „Przegląd Nauk Historycznych” R. 15, 2016, nr 2, s. 120121; J. D ąb row ski, Wtadystaw I Jagiellończyk na Wegrzech (1440-1444), Warszawa 1922 (wznowienie: Oświęcim 2015), s. 196. Zob. także: A. Kr awi e c, op. cit., s. 238. 
Dziejopis wspomina także o haniebnych i szpetnych obyczajach (turpes et fedos ${ }^{57}$ ) Władysława Laskonogiego, którym poddani pogardzali z powodu jego plugawego i rozpustnego życia (propter libidines et spurcicias suas ${ }^{8}$ ).

Podsumowując rozważania nad przekazami Jana Długosza, można zauważyć, że jedną z głównych funkcji Długoszowego podania o Bolesławie Szczodrym, nieposkromionym wojowniku, było ukazanie upadku tego władcy. Takie ujęcie powodowało, że kwestie dotyczące obyczajowości i moralności zostały szczególnie wyeksponowane w narracji. Pod piórem Długosza opowieść o Bolesławie II przybrała kształt umoralniającego exemplum o grzeszniku, który nie chciał odstąpić od grzechu sodomskiego pod wpływem napomnień biskupa krakowskiego Stanisława ${ }^{59}$. Przebieg wydarzeń został przedstawiony zgodnie z chrześcijańską koncepcją dziejów, według której wszelkie nieszczęścia dotykające daną społeczność stanowiły karę zesłaną przez Boga za popełnione grzechy. Następstwa sodomskiego grzechu monarchy, w ujęciu kronikarza, ponosili wszyscy poddani ${ }^{60}$.

Postępowanie Bolesława i polskiego rycerstwa, u których pragnienie rozrywki wzięło górę nad nakazami moralnymi, doprowadziło do zmian w sferze moralnej i obyczajowej, a w konsekwencji przyczyniło się do upadku monarchy. W przekonaniu Jana Długosza pomiędzy zepsuciem moralnym Bolesława a jego upadkiem istniał ścisły związek przyczynowy. W wyniku kontaktów z mieszkańcami Kijowa przewartościowaniu uległ pierwotny, pozytywny wizerunek władcy-wojownika. Kulminacyjnym punktem niegodziwego życia Bolesława było zamordowanie przez niego biskupa krakowskiego Stanisława.

Jak zauważono powyżej, Jan Długosz wkomponował w wizerunek Bolesława Szczodrego motyw zboczenia seksualnego, wiążąc go, bez podstawy źródłowej, z Rusinami. Funkcjonujący w piśmiennictwie od czasów Wincentego z Kielc zarzut królewskiej sodomii kierowany pod adresem Bolesława II pod piórem XV-wiecznego dziejopisa zyskał nie tylko przejrzystość, ale został wzbogacony o nowe elementy. Na tle zarysowanych wydarzeń krakowski kanonik w zawoalowany sposób ukazał odmienność ruskiego kręgu kulturowego od tego, który został wytworzony w łonie łacińskiego Zachodu, wskazując jednocześnie, jak zgubne w skutkach i niebezpieczne mogą być kontakty z odmienną cywilizacją.

Motyw przekroczenia przyjętych przez Kościół norm obyczajowości seksualnej przez Bolesława Szczodrego odgrywa w Długoszowej narracji istotną rolę w opisie społeczności

57 Ioannis Dlugossii Annalesseu Cronicae incliti Regni Poloniae, lib. V-VI, Varsaviae 1973, s. 254.

58 Ibidem, s. 260.

59 Zob. Ioannis Dlugossii Annales, lib. III, s. 123, 127, 130, 133.

60 W relacji zanotowanej pod 1076 r. Jan Długosz wyraził przekonanie, że winę za nieszczęścia i klęski, które spadły na poddanych Bolesława II, ponosił władca, bo to na nim ciążył grzech sodomski: „Propter quod rex et in flagicium horrendum et in quelibet alia subditorum suorum gravissimam oppressionem et perniciem secum trahencia fascinora, nullo monitore castigatus licenciosus grassabatur", Ioannis Dlugossii Annales, lib. III, s.123. Zob. także: ibidem, s. 144. 
spoza własnego kręgu kulturowego. Prezentowane przez dziejopisa wypadki zostały wpisane w schemat „swój-obcy”, w którym Rusini, jako innowiercy i cudzoziemcy, zostali ukazani zgodnie z zachodnioeuropejskimi wyobrażeniami wschodniej cywilizacji. W tych wyobrażeniach posądzenie o zboczenia seksualne często pojawiało się w stereotypie Greka, jaki wytworzono w średniowiecznej Europie łacińskiej ${ }^{61}$.

Zarzut sodomii przypisany przez Jana Długosza Rusinom jako „obcym” nie jest odosobnionym przypadkiem w średniowiecznym pisarstwie. Zachowane źródła poświadczają jednoznacznie negatywny stosunek ich autorów wobec wszelkich zachowań contra naturam oraz wykorzystywanie zarzutu sodomii w charakterze inwektywy. Średniowieczni kronikarze, argumentując własne poglądy, niejednokrotnie sięgali nie tylko po racje intelektualne. Zniewaga słowna, będąca skutecznym narzędziem oczerniania przeciwnika, często stanowiła element napastliwego ataku słownego lub polemiki. Wśród różnego rodzaju inwektyw zniesławiających istotne miejsce zajmowało oskarżenie o sodomię, nader hańbiące i deprecjonujące, przy czym mniejsze znaczenie miał fakt prawdziwości owych zarzutów ${ }^{62}$. Wykorzystywanie przez kronikarzy posądzenia o sodomię nierzadko było próbą przypisania przeciwnikom gorszących występków, a nie zamiarem ujawnienia ich nieprzyzwoitych praktyk. W średniowiecznym piśmiennictwie niejednokrotnie obwiniano o sodomię „obcych” w kontekście ich przywary narodowej. Przykład stanowi Florencja, której mieszkańcy zasłynęli z sodomickich zachowań do tego stopnia, że w potocznej niemczyźnie pojawiło się wówczas słowo florentzen oznaczające „odbywać stosunek homoseksualny”63. Zarzut sodomii kierowano również pod adresem heretyków ${ }^{64}$ czy Normanów ${ }^{65}$. Nierzadko posądzenie o sodomię, jako skuteczny oręż w walce z przeciwnikiem, miało charakter polityczny ${ }^{66}$. W tym kontekście oskarżenia tego rodzaju użyto przeciwko francuskim templariuszom ${ }^{67}$.

Chrześcijanie obwiniali o ten grzech skłonności wyznawców islamu ${ }^{68}$. Czytelne oskarżenie muzułmanów o sodomię zawiera list przypisywany Aleksemu Komnenowi

${ }_{61}$ J. Le Goff, Kultura średniowiecznej Europy, ttum. H. Szu mańsk a-G rossowa, Warszawa 1970, s. 148 in.

62 K. Skwierczyński, Mury sodomy..., s. 50; R.M. Karras,op. cit., s. 195.

63 R.M. Ka r r a s, op. cit., s. 189-194; H. Puff, Sodomy in Reformation Germany and Switzerland, 1400-1600, Chicago 2003, s. 13 in.

64 Powiązania heretyków z sodomią R.M. Karras upatruje w zarzutach, jakie stawiano wobec Katarów, których oskarżano o nieprokreacyjne akty seksualne (R.M. Karras, op. cit., s. 181. Zob także: K. Ren a to Lings, op. cit., s. 305). W późnośredniowiecznych Niemczech słowo Ketzer (heretyk) było powszechnie używane na określenie sodomity. Zob.: R.M. Karras, op. cit., s. 181; H. Puff, Nature on Trial..., s. 237; id e m, Sodomy in Reformation..., s. 17, 23-24 in.

65 H.M. Tho mas, The English and the Normans: Ethnic Hostility, Assimilation, and Identity 1066-c.1220, Oxford 2003, s. 329;R.M. Karras, op. cit., s. 181; K. Skwierczyński, Mury sodomy..., s. 50.

66 R.M. Karras, op. cit., s. 195.

67 Ibidem.

68 K. Skwierczyński, Mury sodomy..., s. 50-52; R.M. Karras, op. cit., s. 181-183. 
wzywającemu Zachód do krucjaty przeciw niewiernym. Wśród katalogu grzechów przypisanych w tym dokumencie muzułmanom znalazło się także posądzenie, że hańbili oni grzechem sodomskim chrześcijańskich mężczyzn, nie zważając na wiek i stan ${ }^{69}$.

Kronikarskie przekazy Jana Długosza, wypełnione licznymi motywami, posłużyły dziejopisowi do „modelowania” rzeczywistości w duchu negatywnych przekonań na temat obyczajowości Rusinów. Opis wyprawy kijowskiej, podczas której doszło do zepsucia moralnego Bolesława, pod piórem Jana Długosza nabrał wyraźnie antyruskiej wymowy. Długoszowa wypowiedź, sformułowana w określonym kontekście politycznym, społecznym i historycznym, ma charakter silnie wartościujący. Zarzuty rozpusty i sodomii skierowane pod adresem Rusinów uwypuklą w narracji „godne potępienia"70 ruskie obyczaje (Ruthenorum detestabiles mores ${ }^{71}$ ) i podkreślą ich obcość obyczajową. W konfrontacji z Polakami Rusini ukazani zostali jako lud stojący niżej na drabinie moralności. Tym samym kronikarz sygnalizuje nie tylko „obcość” Rusinów, ale także ich moralną i obyczajową niższość.

\section{BIBLIOGRAFIA}

Źródła drukowane:

Chronica Dzirsvae, [w:] Monumenta Poloniae Historica, Nova Series, t. 15, wyd., wstępem i przyp. opatrzył K. Pawłowski, Kraków 2013.

Chronica Poloniae Maioris, ed. B. Kürbis, [w:] Monumenta Poloniae Historica, Nova Series, t. 8, Warszawa 1970.

Chronica polonorum, [w:] Monumenta Poloniae Historica, t. 3, ed. L. Ćwikliński, Lwów 1878.

Jana Dtugosza Roczniki czyli Kroniki Stawnego Królestwa Polskiego, ks. III-IV, tłum. J. Mrukówna, Warszawa 2009.

Ioannis Dlugossii Annales seu Cronicae incliti Regni Poloniae, lib. III-IV, Varsaviae 1970.

Ioannis Dlugossii Annales seu Cronicae incliti Regni Poloniae, lib. V-VI, Varsaviae 1973.

Joannis Dlugossii Annales seu cronicae incliti regni Poloniae, lib. XI-XII, Varsaviae 2001.

Księga Rodzaju, [w:] Pismo Święte Starego i Nowego Testamentu, red. K. Dynarski, M. Przyby1, wyd. 5, Poznań 2008.

Magistri Vincenti dicti Kadtubek Chronica Polonorum, ed. M. Plezia, [w:] Monumenta Poloniae Historica, Nova Series, t. 11, Kraków 1994.

Poviest' vremennych let, č. 1, wyd. D.C. Lichačev, Moskwa-Leningrad 1950.

Tomasz z Akwinu, Suma teologiczna, t. 22: Umiarkowanie, tłum. S. Bełch, London 1993.

Vita sancti Stanislai episcopi Cracoviensis (Vita maior), [w:] Monumenta Poloniae Historica, t. 4, ed. W. Kętrzyński, Lwów 1884.

${ }_{69}$ J. B o s w ell, Chrześcijaństwo, tolerancja spoteczna i homoseksualność. Geje i lesbijki w Europie Zachodniej od początku ery chrześcijańskiej do XIV wieku, tłum. J. Kr zy sz p i eń, Kraków 2006, s. 253; R.M. Ka r r as, op. cit., s. 181-183; K. Skwierczyński, Mury sodomy..., s. 50-51.

70 Jana Dtugosza Roczniki, ks. III, s. 142.

$71 \quad$ Ioannis Dlugossii Annales, lib. III, s. 121. 
Vita sancti Stanislai episcopi Cracoviensis (Vita minor), [w:] Monumenta Poloniae Historica, t. 4, ed. W. Kętrzyński, Lwów 1884.

Vita sanctissimi Stanislai, ed. I. Polkowski, Ż. Pauli, [w:] Joannis Dlugossii Senioris Canonici Cracoviensis, Opera omnia, t. 1, Kraków 1887.

\section{Opracowania:}

Banaszkiewicz J., Czarna i biata legenda Bolestawa Śmiatego, „Kwartalnik Historyczny” R. 88, $1981, \mathrm{nr} 2$.

Banaszkiewicz J., Trzy razy uczta, [w:] Spoteczeństwo Polski średniowiecznej, t. 5, red. S.K. Kuczyński, Warszawa 1992.

Bartnicki M., Wtadca i poddani w historiografii ruskiej XI-XIII wieku, Lublin 2015.

Benyskiewicz K., W kregu Bolestawa Szczodrego i Wtadystawa Hermana. Piastowie w matżenstwie, polityce i intrydze, Wrocław 2010.

Bloomfield M.W., The Seven Deadly Sins: An Introduction to the History of a Religious Concept, with Special Reference to Medieval English Literature, Michigan 1952, https://doi. org/10.2307/3161319.

Boswell J., Chrześcijaństwo, tolerancja spoteczna i homoseksualność. Geje i lesbijki w Europie Zachodniej od początku ery chrześcijańskiej do XIV wieku, tłum. J. Krzyszpień, Kraków 2006.

D’Anlgelo E., San Pier Damiani, „Liber Gomorrbianus”. Omosessualita ecclesiastica e rifonna della Chiesa, Alessandria 2001.

Dąbrowski J., Wtadystaw I Jagiellończyk na Wegrzech (1440-1444), Warszawa 1922 (wznowienie: Oświęcim 2015).

Delestowicz N., Bolestaw II Szczodry. Tragiczne losy wielkiego wojownika 1040/1042-2/3 IV 1081 albo 1082, Kraków 2016.

Dygo M., Uczty Bolestawa Chrobrego, „Kwartalnik Historyczny” R. 112, 2005, nr 3, s. 41-54.

Geremek B., Cztowiek i zabawa: kultura ludyczna,[w:] Kultura Polski średniowiecznej XIV-XVw., red. B. Geremek, Warszawa 1997.

Gołuchowski A.R., Biblijna problematyka miasta Sodomy, „Kieleckie Studia Teologiczne” 2009, t. 8, s. 309-334.

Grudziński T., Bolestaw Śmiaty-Szczodry i biskup Stanistaw. Dzieje konfliktu, Warszawa 1986.

Hergemöller B.-U., Sodomiter. Schuldzuschreibung und Repressionformen im späten Mittelalter, [w:] Randgruppen der spätmittelalterlichen Gesellschaft. Ein Hand-und Studienbuch, Hrsg. B.-U. Hergemöller, Warendorf 1994.

Hergemöller B.-U., Średniowiecze, [w:] Geje i lesbijki. Życie i kultura, red. R. Aldrich, tłum. P. Nowakowski, Kraków 2009.

Hojka J., Sodoma i Gomora, „Ruch Biblijny i Liturgiczny” 1961, vol. 14, nr 6, s. 284-291, https:// doi.org/10.21906/rbl.2844.

Johansson W., Percy W.A., Homosexuality, [w:] Handbook of Medieval Sexuality, eds. V.L. Bullough, J.A. Brundage, New York-London, 1996.

Jordan M.D., Sodomy, [w:] Gay Histories and Cultures. An Encyclopedia, (The Encyclopedia of Lesbian and Gay Histories and Cultures, vol. 2), ed. G. Haggerty, New York 2012.

Jordan M. D., The Invention of Sodomy in Christian Theology, Chicago 1997.

Karras R.M., Seksualność w średniowiecznej Europie, tłum. A. Bugaj, Warszawa 2012.

Krawiec A., Seksualność w średniowiecznej Polsce, Poznań 2000.

Krotoski K., Święty Stanisław biskup w świetle źródeł: rozbiór krytyczny źródeł odnoszących się do kwestyi Ś. Stanistawa bisk., Kraków 1902. 
Kürbis B., Jak mistrz Wincenty pojmowat historię Polski, „Studia Źródłoznawcze” 1976, t. 20, s. 64-70.

Kuzmová S., Preaching Saint Stanislaus. Medieval Sermons on Saint Stanislaus of Cracow and Their Role in the Construction of His Image and Cult, Budapest 2010.

Le Goff J., Kultura średniowiecznej Europy, tłum. H. Szumańska-Grossowa, Warszawa 1970.

Le Goff J., Truong N., Historia ciata w'sedniowieczu, tłum. I. Kania, Warszawa 2006.

Lewandowski P., Grzech sodomii w przestrzeni politycznej, prawnej i spotecznej Polski nowożytnej, Wyd. E-bookowo, 2014.

Mrozowicz W., Święty Stanistaw w średniowiecznym dziejopisarstwie ślaskim, [w:] Kult św. Stanistawa na Ślasku (1253-2003), red. A. Pobóg-Lenartowicz, Opole 2004.

Nadolski A., Dankowa J., Uwagi o sktadzie i uzbrojeniu polskiej jazdy rycerskiej w latach 1350-1450, „Studia i Materiały do Historii Wojskowości” 1983, vol. 26, s. 91-110.

Pac G., Kobiety w dynastii Piastów. Rola spoteczna piastowskich żon i córek do potowy XII wieku-studium porównawcze, Toruń 2013.

Plezia M., Dookota sprawy św. Stanistawa. Studium źródtoznawcze, Bydgoszcz 1999.

Plezia M., Od Arystotelesa do „ztotej legendy”, Warszawa 1959.

Powierski J., Kryzys rządów Bolestawa Śmiatego. Polityka i jej odzwierciedlenie w literaturze średniowiecznej, Gdańsk 1992.

Puff H., Nature on Trial. Acts "Against Nature” in the Law Courts of Early Modern Germany and Switzerland, [w:] The Moral Authority of Nature, eds. L. Daston, F. Vidal, Chicago 2010.

H. Puff, Sodomy in Reformation Germany and Switzerland, 1400-1600, Chicago 2003.

Renato Lings K., Love Lost in Translation: Homosexuality and the Bible, Trafford Publishing, 2013.

Sielicki F., Polsko-ruskie stosunki kulturalne do końca XV wieku, Wrocław 1997.

Skibiński E., Biskup i monarcha, [w:] Docendodiscimus. Studia historyczne ofiarowane Profesorowi Zbigniewowi Wielgoszowi w siedemdziesiąta rocznice urodzin, red. K. Kaczmarek, J. Nikodem, Poznań 2000.

Skwierczyński K., Mury Sodomy. Piotra Damianiego „Księga Gomory” i walka z sodomia wśród kleru, Kraków 2011.

Skwierczyński K., Walka z sodomią wśród kleru -„Liber Gomorrhianus” Piotra Damianiego, „Przegląd Humanistyczny” 2007, t. 98, z. 3, s. 369-382.

Sroka S.A., Stawa, chwata i plotka. Wtadystaw Warneńczyk jako król Wegier, „Przegląd Nauk Historycznych” R. 15, 2016, nr 2, s. 103-126, https://doi.org/10.18778/1644-857X.15.02.04.

Thomas H.M., The English and the Normans: Ethnic Hostility, Assimilation, and Identity 1066c. 1220, Oxford 2003.

Wółkiewicz E., Grube ciato. Spoteczne postrzeganie otytości w średniowieczu, „Przegląd Historyczny” 2009, t. 100, z. 3, s. 495-524.

Zaremska H., Grzech i występek. Normy i praktyka moralności spotecznej, [w:] Kultura Polski średniowiecznej XIV-XVw., red. B. Geremek, Warszawa 1997.

Żmudzki P., Mieszko I i Amazonki. Wspólnoty wojownicze i normy życia rodzinnego w relacji Ibrabima ibn Jakuba, [w:] Tekst źródta, krytyka, interpretacja, red. B. Trelińska, Warszawa 2005.

Żmudzki P., Wtadca i wojownicy. Narracje o wodzach, drużynie i wojnach w najdawniejszej historiografii polskiej i ruskiej, Wrocław 2009. 